\title{
PENGARUH POLA ANYAMAN TERHADAP KEKUATAN TARIK DAN BENDING KOMPOSIT BERPENGUAT SERAT BAMBU
}

\author{
Abd. Kadir ${ }^{1}$, Aminur ${ }^{1}$, Marzan ${ }^{2}$ \\ ${ }^{1}$ Staf Pengajar Program Studi Teknik Mesin Fakultas Teknik Universitas Halu Oleo \\ Kampus Hijau Bumi Tridarma Andounohu Kendari 93232 \\ ${ }^{2}$ Mahasiswa Program Studi Teknik Mesin Fakultas Teknik Universitas Halu Oleo \\ Kampus Hijau Bumi Tridarma Andounohu Kendari 93232 \\ E-mail: abdkadirsyam@yahoo.co.id
}

\begin{abstract}
Komposit serat bambu merupakan salah satu komposit serat alam. Untuk mendapatkan kekuatan komposit maksimal maka serat dapat dibuat dalam bentuk anyaman. Tujuan penelitian ini untuk mengetahui pengaruh pola anyaman terhadap kekuatan tarik dan bending komposit berpenguat serat bambu. Bahan yang digunakan adalah serat bambu apus dan bahan matrik adalah ressin polyester dan pola anyaman adalah plain, twill dan random. Pengujian spesimen berdasarkan standar ASTM D 638-01 untuk uji tarik dan standar ASTM D 790-02 untuk uji bending. Hasil pengujian menunjukan nilai uji tarik tertinggi terdapat pada komposit dengan anyaman plain ( 20,234 N/mm²), sedangkan nilai kekuatan tarik terendah terdapat pada komposit dengan anyaman random $\left(3,451 \mathrm{~N} / \mathrm{mm}^{2}\right)$. Pada pengujian bending, nilai kekuatan bending tertinggi terdapat pada anyaman plain $\left(41,707 \mathrm{~N} / \mathrm{mm}^{2}\right)$, sedangkan nilai kekuatan bending terendah terdapat pada anyaman random $\left(15,061 \mathrm{~N} / \mathrm{mm}^{2}\right)$.
\end{abstract}

Keywords : komposit, anyaman, pola, uji tarik, uji bending

\begin{abstract}
Abstrak
The effect of the woven pattern on the tensile and bending strength of the bamboo fiber composite. Bamboo fiber composite is one of the natural fiber composites. To obtain the maximum strength of the composite fiber, it can be constructed in the form of woven. The purpose of this study is to determine the effect of the woven pattern on the tensile and bending strength of the bamboo fiber composite. It uses a leer bamboo fiber with the resin polyester matrix materials in various woven patterns: plain, twill and random. The test on the specimen is based on the standard of ASTM D 638-01 for the tensile test and that of the standard of ASTM D 790-02 for the bending test. The results show the highest tensile strength is obtained by the composite with plain woven $\left(20.234 \mathrm{~N} / \mathrm{mm}^{2}\right)$, while the lowest is obtained the composites with random woven $\left(3.451 \mathrm{~N} / \mathrm{mm}^{2}\right)$. In the bending test, the highest bending strength is obtained by the plain woven $\left(41.707 \mathrm{~N} / \mathrm{mm}^{2}\right)$, while the lowest value is obtained by the random one $\left(15.061 \mathrm{~N} / \mathrm{mm}^{2}\right)$.
\end{abstract}

Kata Kunci: composite, woven, pattern, tensile test, bending test

\section{Pendahuluan}

Indonesia merupakan negara yang kaya akan aneka tumbuhan, yang salah satunya adalah bambu. Tanaman bambu di Indonesia dapat ditemukan mulai dari dataran rendah sampai pegunungan, yang pada umumnya ditemukan beberapa tempat terbuka dan bebas dari genangan air.
Bambu adalah tanaman jenis rumput-rumputan dengan rongga dan ruas di batangnya. Nama lain dari bambu adalah buluh, aur dan eru. Di dunia ini, bambu merupakan salah satu tanaman dengan pertumbuhan paling cepat yang tergantung pada kondisi tanah dan klimatologi tempat bambu ditanam. 
Dalam kehidupan masyarakat pedesaan di Indonesia, bambu memegang peranan yang sangat penting. Bahan bambu dikenal oleh masyarakat memiliki sifat-sifat yang baik untuk dimanfaatkan karena batangnya kuat, lurus, rata, keras, mudah dibelah, mudah dibentuk, dan mudah dikerjakan serta mudah diangkut. Selain itu bambu juga relatif lebih murah dibanding bahan bangunan lain karena banyak ditemukan di sekitar pemukiman pedesaan (Widjaja, 2001).

Serat bambu merupakan salah satu serat alam yang dapat dijadikan bahan penguat komposit. Salah satu keunggulan serat alam yaitu elastis, kuat, bahan baku melimpah, ramah lingkungan dan pembuatannya mengkomsumsi energi sekitar $70 \%$, yang lebih rendah dibandingkan dengan komposit polimer serat gelas (Jensen, 1987).

Serat merupakan salah satu unsur dari komposit karena serat dapat menentukan karakteristik suatu bahan seperti kekuatan, keuletan, kekakuan dan sifat mekanik yang lain. Aspek lain yang juga menentukan karakteristik komposit adalah pola anyaman serat. Tujuan dari penelitian ini adalah untuk mengetahui pengaruh pola anyaman terhadap kekuatan tarik dan bending komposit berpenguat serat bambu.

\section{Kajian Literatur}

\section{Penelitian bambu dan komposit}

Sebuah penelitian yang dilakukan oleh Janssen (1987) pada sifat mekanik bambu menunjukkan bahwa kekuatan lentur rata-rata adalah sebesar 84 MPa, dengan modulus elastisitas sebesar 20.000 $\mathrm{MPa}$. Kekuatan geser rata-rata relatif rendah, (2,25 Mpa) pada pembebanan jangka pendek, dan 1 MPa pada pembebanan jangka panjang $(6-12$ bulan). Pada penelitian ini juga menunjukan bahwa bambu mampu menahan kekuatan yang cukup tinggi (200 - $300 \mathrm{Mpa})$.

Penelitian tentang bambu juga dilakukan oleh Morisco (1999). Penelitian ini didorong oleh kenyataan bahwa kuat tarik bambu sangat tinggi, sedangkan dalam praktek kekuatan ini belum dimanfaatkan karena belum adanya metode penyambungan bambu yang dapat menghasilkan sambungan dengan kekuatan yang memadai. Dengan membandingkan pada kekuatan baja, hasil dari pengujian menunjukan bahwa kekuatan bambu jenis ori cukup tinggi yaitu hampir mencapai $500 \mathrm{Mpa}$ (sekitar 2 kali tegangan leleh baja). Pada perbandingan dengan bambu jenis petung, kekuatan tarik rata-rata juga lebih tinggi dari tegangan leleh baja.

Taufik dkk (2013) malakukan penelitian tentang kekuatan pada serat kulit bambu apus. Dari hasil pada sebuah pengujian spesimen uji menunjukan bahwa kekuatan tarik pada spesimen resin murni sebesar 2.11 MPa. Hasil pengujian yang lain menunjukan bahwa kekuatan tarik maksimum pada komposit polimer dengan serat bambu dengan komposisi $10 \% 15 \%$ dan $20 \%$ berturutturut adalah $38.11 \mathrm{MPa}, 55,8 \mathrm{MPa}$ dan 86.01 MPa. Hasil dari penelitian ini menunjukan bahwa penambahan serat pada komposit sangat berpengaruh pada kekuatan tariknya.

Pramono (2008) melakukan penelitian pengaruh serat enceng gondok (eichornia crassipes) terhadap kekuatan tarik pada komposit dengan matrik unsaturated polyester yukalac tipe 157 BQTN-EX. Hasil pengujian menunjukkan tegangan tarik tebesar terjadi pada serat non perlakuan $\left(27.397 \mathrm{~N} / \mathrm{mm}^{2}\right)$, namun elongasinya menunjukkan nilai yang terendah $(0.857 \%)$.

Pada sebuah penelitian komposit dengan serat bambu yang dilakukan oleh Taurista dkk (2006) menunjukan bahwa kekuatan tarik terbesar dimiliki oleh komposit dengan lebar serat $5 \mathrm{~mm}$ dengan nilai kekuatan tarik sebesar 16,806 $\mathrm{Kg} / \mathrm{mm}^{2}$. Regangan tarik terbesar dimiliki komposit dengan lebar serat $5 \mathrm{~mm}$ dengan nilai regangan sebesar $0,012 \%$. Modulus elastisitas tarik terbesar dimiliki komposit dengan lebar serat $5 \mathrm{~mm}$ dengan nilai sebesar 1421,129 $\mathrm{kg} / \mathrm{mm}^{2}$. Kekuatan bending terbesar dimiliki oleh komposit dengan lebar serat $5 \mathrm{~mm}$ dengan nilai $17,60533 \mathrm{~kg} / \mathrm{mm}^{2}$. Hasil-hasil ini sudah memenuhi syarat untuk aplikasi material kulit kapal, sesuai standar BKI (Biro Klasifikasi Indonesia).

Diharjo (2006) melakukan sebuah pengamatan visual untuk menyelidiki mekanisme perpatahan pada komposit serat rami, yang sebelumnya direndam di dalam larutan alkali $(5 \% \mathrm{NaOH})$ dengan waktu yang berbeda. Hasil pengamatan menunjukan bahwa komposit yang diperkuat serat rami dengan perlakuan 5\% $\mathrm{NaOH}$ selama 2 jam memiliki kekuatan tarik dan regangan terbesar (190.27 Mpa-tarik, 0.44\%-regangan). 


\section{Komposit}

Kata komposit berasal dari kata "to compose" yang berarti menyusun atau menggabung. Secara sederhana bahan komposit berarti bahan gabungan dari dua atau lebih bahan yang berlainan. Jadi komposit adalah suatu bahan yang merupakan gabungan atau campuran dari dua material atau lebih pada skala makroskopis untuk membentuk material ketiga yang lebih bermanfaat (Jones, 1975).

Komposit dan paduan (alloy) memiliki perbedaan dari cara penggabungannya. Komposit digabung secara makroskopis sehingga masih kelihatan serat maupun matriknya (komposit serat), sedangkan pada paduan (alloy) digabung secara mikroskopis sehingga tidak kelihatan lagi unsurunsur pendukungnya. Pada material komposit sifat unsur pendukungnya masih terlihat dengan jelas, sedangkan pada paduan sudah tidak kelihatan lagi. Salah satu keunggulan dari material komposit bila dibandingkan dengan material lainnya adalah penggabungan unsurunsur yang unggul dari masing-masing unsur pembentuknya. Sifat material hasil penggabungan ini diharapkan dapat saling melengkapi kelemahan-kelemahan yang ada pada masing-masing material penyusunnya. Sifat-sifat bahan komposit yang dapat diperbaharui antara lain kekuatan, kekakuan, ketahanan korosi, ketahanan gesek/aus, berat, ketahanan lelah, konduktivitas panas dan tahan lama (Jones, 1975).

Bahan komposit mempunyai beberapa kelebihan dibanding dengan bahan konvensional seperti logam. Beberapa kelebihan tersebut antara lain sifat mekanik dan fisik yang baik, mudah dibentuk dan biaya produksi yang murah (Hendra, 2002).

\section{Unsur utama pembentuk komposit}

Unsur utama dari bahan komposit adalah serat. Serat inilah yang menentukan karakteristik suatu bahan seperti kekuatan, keuletan, kekakuan dan sifat mekanik yang lain. Serat menahan sebagian besar gaya yang bekerja pada material komposit, sedangkan matriks mengikat serat, melindungi dan meneruskan gaya antar serat (Vlack, 2005).

\section{Matriks}

Menurut Gibson (1994), bahwa matrik dalam struktur komposit dapat berasal dari bahan polimer, logam dan keramik. Syarat pokok matrik yang digunakan dalam komposit adalah matrik harus bisa meneruskan beban, sehinga serat harus bisa melekat pada matrik dan kompatibel antara serat dan matrik. Umumnya matrik yang digunakan memiliki ketahanan panas yang tinggi.

Menurut Diharjo (2006) pada bahan komposit matrik mempunyai kegunaan dalam memegang dan mempertahankan serat pada posisinya. Selain itu, pada saat terjadi pembebanan, matrik dapat merubah bentuk dan mendistribusikan tegangan ke unsur utamanya yaitu serat. Matrik juga dapat memberikan sifat tertentu, misalnya elastisitas, keuletan dan konduktivitas.

Menurut Diharjo (2006), bahan matrik yang sering digunakan dalam komposit adalah thermoset (plastik atau resin yang tidak bisa berubah karena panas tidak bisa di daur ulang), thermoplastic (plastik atau resin yang dapat dilunakkan terus menerus dengan pemanasan atau dikeraskan dengan pendinginan dan bisa berubah karena panas (bisa didaur ulang)), keramik, karet (polimer bersistem cross linked yang mempunyai kondisi semi kristalin dibawah temperatur kamar), logam dan karbon.

\section{Serat (Fiber)}

Serat atau fiber dalam bahan komposit berperan sebagai bagian utama yang menahan beban. Besar kecilnya kekuatan bahan komposit sangat tergantung dari kekuatan serat pembentuknya. Semakin kecil bahan (diameter serat mendekati ukuran kristal), maka semakin kuat bahan tersebut, karena minimnya cacat pada material (Diharjo, 2006).

Selain itu serat (fiber) juga merupakan unsur yang terpenting, karena serat dapat menentukan sifat mekanik komposit tersebut seperti kekerasan, keuletan dan kekuatan. Fungsi utama dari serat adalah sebagai pembawa beban, memberikan sifat kekakuan, kekuatan dan stabilitas panas dan memberikan insulasi kelistrikan pada komposit (Diharjo, 2006).

Serat alam adalah serat yang dapat langsung diperoleh dari alam. Biasanya berupa serat yang dapat langsung diperoleh dari tumbuh-tumbuhan 
dan binatang. Serat ini telah banyak digunakan oleh manusia diantaranya adalah kapas, wol, sutera, pelepah pisang, sabut kelapa, ijuk, bambu, nanas dan goni. Serat alam memiliki kelemahan yaitu ukuran serat yang tidak seragam dan kekuatan seratnya sangat dipengaruhi oleh usia (Bismarck, dkk 2002).

Menurut Biswas dkk (2001), beberapa karakteristik yang merupakan kelebihan dari komposit yang diperkuat oleh serat alam yaitu dapat dicat, dipoles dan dilaminasi, tahan terhadap penyerapan air, kuat, kaku dan ramah lingkungan. Di samping kelebihan, komposit serat alam juga memiliki beberapa kelemahan. Kekuatan komposit serat alam dapat menurun karena faktor biologis, karena panas dan karena radiasi ultraviolet (Rowell, 1997).

Schwartz (1984) menjelaskan bahwa serat sebagai penguat dalam struktur komposit harus memenuhi persyaratan modulus elastisitas yang tinggi, kekuatan patah yang tinggi, kekuatan yang seragam di antara serat, stabil selama penanganan proses produksi dan diameter serat yang seragam.

\section{Tanaman bambu}

Bambu dikenal oleh masyarakat memiliki sifatsifat yang baik untuk dimanfaatkan. Sifat-sifat tersebut antara lain batangnya kuat, ulet, lurus, rata, keras, mudah dibelah, mudah dibentuk, mudah dikerjakan dan ringan. Selain itu tanaman bambu mempunyai ketahanan yang luar biasa. Bambu juga elastis, sehingga struktur bambu mempunyai ketahanan yang tinggi baik terhadap angin maupun gempa (Morisco, 1999).

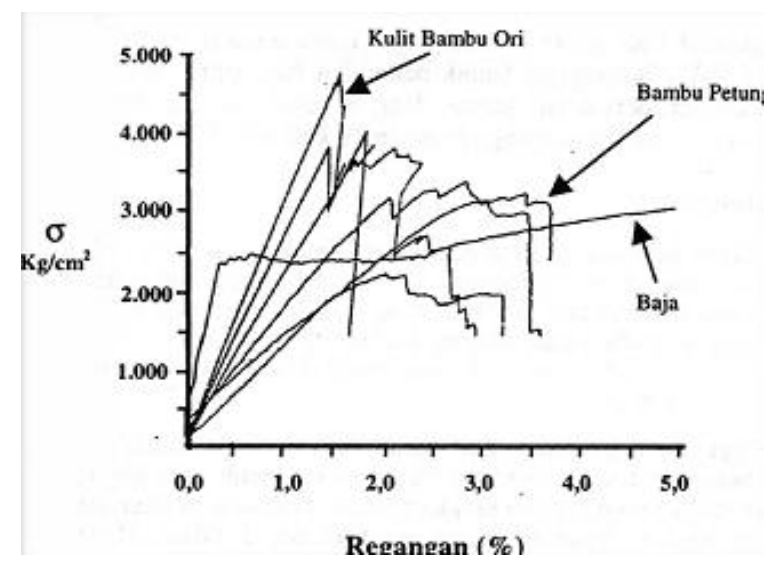

Gambar 1. Diagram tegangan-regangan bambu dan baja (Morisco, 1999)

\section{Pola anyaman}

Selain bahan matrik dan serat, pola anyaman dapat mempengaruhi kekuatan komposit. Beberapa model pola anyaman yang dikembangan antara lain anyaman polos (plain), basket, satin, twill dan kombinasinya. Pola anyaman memiliki jenis orientasi pakan/warp dan lusi/weft yang homogen maupun hibrida. Ada 3 anyaman dasar yang banyak digunakan seperti plain, twill dan satin dengan beberapa variasi (Alimaskur, 2011).

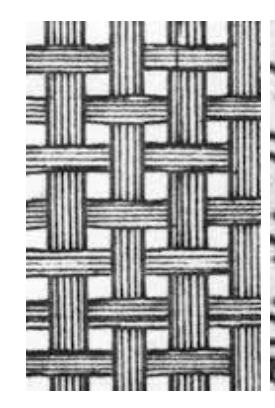

(a)

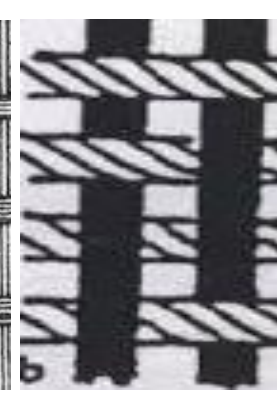

(b)

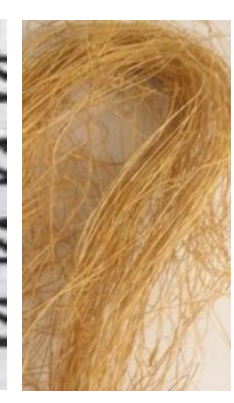

(c)
Gambar 2. Pola anyaman : a). Plain, b). Twill, c) Random (sumber :Alimaskur, 2011)

Anyaman plain merupakan anyaman paling sederhana, paling tua dan paling banyak dipakai. Anyaman ini mempunyai tingkat kesulitan pembuatan yang paling kecil dibanding semua jenis anyaman. Jumlah silangan dalam anyaman ini paling banyak di antara jenis anyaman yang lain. Selain itu, anyaman ini sering dikombinasikan dengan beberapa faktor kontruksi yang lain dari jenis anyaman yang lainnya (Alimaskur, 2011).

Anyaman twill memiliki nama lain drill (Inggris) dan Koper (Jerman). Anyaman twill adalah anyaman dasar kedua. Pada permukaan kain dengan anyaman ini, terlihat garis miring yang tidak putus. Jika garis miring berjalan dari kanan bawah ke kiri atas disebut twill kiri. Jika garis miring berjalan dari kiri bawah ke kanan atas disebut twill kanan. Garis miring yang dibentuk oleh benang lusi disebut twill efek lusi atau twill lusi. Garis miring yang dibentuk oleh benang pakan disebut twill efek pakan atau twill pakan. Garis miring ini dibentuk $45^{\circ}$ terhadap garis horizontal (Alimaskur, 2011). 


\section{Pengujian kekuatan tarik}

Pengujian tarik bertujuan untuk mengetahui tegangan, regangan dan modulus elastisitas bahan dengan cara menarik spesimen sampai putus. Pengujian tarik dapat dilakukan dengan mesin uji tarik atau dengan universal testing standar (standar ASTM D 638-02).

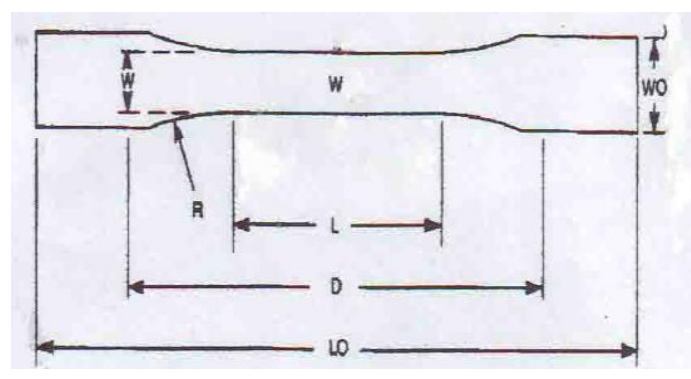

Gambar 3. Spesimen uji tarik

Geometri dan dimensi bahan uji menurut standar ASTM D 638-02 dapat dilihat pada gambar 3. Dalam gambar tersebut, Wo adalah lebar spesimen $(\mathrm{mm}), \mathrm{L}$ adalah panjang daerah ukur $(\mathrm{mm}), \mathrm{W}$ adalah lebar daerah pengujian $(\mathrm{mm})$, Lo adalah panjang spesimen $(\mathrm{mm}), \mathrm{D}$ adalah diameter $(115 \mathrm{~mm})$ dan $\mathrm{R}$ adalah jari-jari bahu (mm).

Gambar 4 menunjukan kurva tegangan regangan pada benda yang diuji tarik. Dari gambar ini, notasi $\mathrm{P}$ adalah batas proposional, di mana penambahan panjang berbanding lurus dengan penambahan beban (berlaku hukum Hooke). Biasanya titik ini dianggap sama dengan titik elastis. Notasi E adalah batas elastis, yang merupakan batas yang menunjukan bahwa beban akan kembali ke bentuk semula bila beban dihilangkan. Notasi $\mathrm{Y}$ adalah yield, yang merupakan batas luluh antara titik Y-E di mana, terjadi penguluran tanpa adanya penambahan beban. Tegangan pada Y disebut tegangan luluh (Yield stress).

Setelah titik Y dilampai, terjadi terjadi perpanjangan plastis hingga titik $U$ yang merupakan batas ultimate. Jika beban diteruskan untuk ditarik hingga di atas tegangan luluh maka tegangan akan naik terus sesuai kenaikan regangan dan kemudian mencapai harga maksimum. Setelah tahap ini, beban akan menurun lagi. Batas ini merupakan batas yang menentukan kekuatan tarik maksimum dan tegangan tarik di sini disebut tegangan tarik. Notasi B adalah batas patah, di mana batang uji akan mengalami patah dan putus karena tegangan akhir yang diterima.

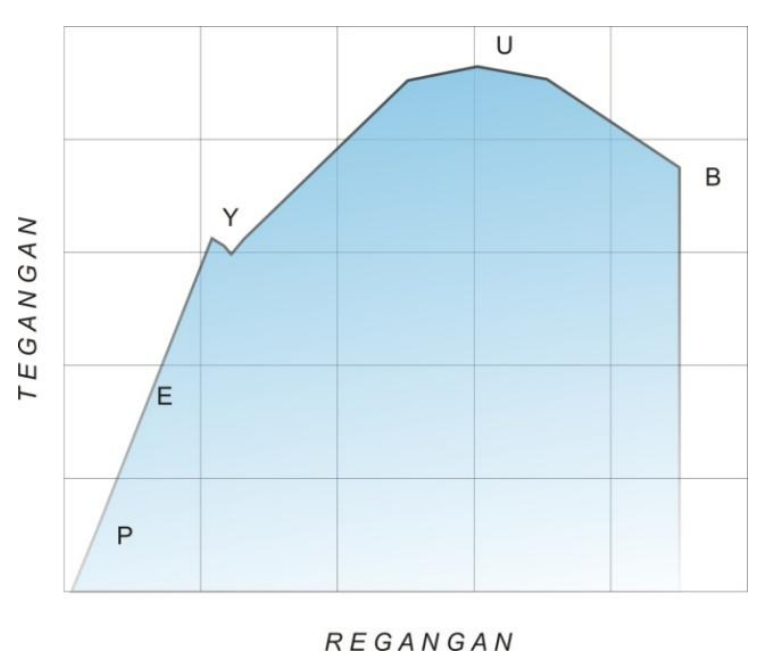

Gambar 4. Kurva tegangan-regangan

Hubungan antara tegangan dan regangan pada beban tarik ditentukan dengan rumus sebagai berikut (Rabiul, 2013).

$\mathrm{F}=\sigma \cdot A$ atau $\sigma=\frac{\mathrm{F}}{A}$

Dimana :

$\mathrm{F}=\operatorname{Beban}(\mathrm{N})$

A $=$ Luas penampang $\left(\mathrm{mm}^{2}\right)$

\section{Pengujian kekutan bending}

Material komposit mempunyai sifat tekan yang lebih baik dibandingkan sifat tariknya. Pada perlakuan uji bending, pada bagian atas spesimen mengalami proses penekanan, dan pada bagian bawah spesimen mengalami proses tarik. Hal ini mengakibatkan spesimen mengalami patah bagian bawah karena tidak mampu menahan tegangan tarik (Simbolon, 2008).

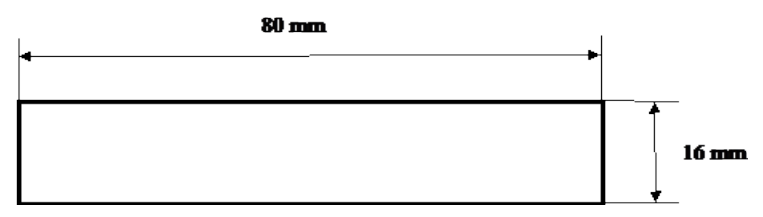

Gambar 5. Spesimen uji bending 
Spesimen uji bending dapat dibuat sesuai standar ASTM D709-02 (gambar 5). Pehitungan kekuatan bending dapat menggunakan persamaan:

$\sigma b=\frac{3 F L}{2 \cdot b \cdot d^{2}}$

Dimana:

$$
\begin{aligned}
\sigma b & =\text { Kekuatan bending }(\mathrm{MPa}) \\
\mathrm{F} & =\text { Gaya tarik }(\mathrm{N}) \\
\mathrm{L} & =\text { Panjang spesimen }(\mathrm{mm}) \\
\mathrm{B} & =\text { Lebar }(\mathrm{mm}) \\
\mathrm{D} & =\text { Tebal }(\mathrm{mm})
\end{aligned}
$$

\section{Metode penelitian}

Penelitian ini dilakukan di Laboratorium Teknologi Mekanik Jurusan Teknik Mesin Fakultas Teknik Universitas Halu Oleo dari bulan Maret 2014 sampai bulan September 2014.

Alat yang digunakan dalam penelitian ini antara lain adalah timbangan digital, cetakan komposit, jangka sorong, gergaji tangan, sendok, cutter, gunting, kuas, pisau, spidol, penggaris, dan malem.

Bahan komposit yang digunakan dalam penelitian ini adalah serat bamboo apus. Serat bambu diperoleh dari proses pengerjaan secara manual. Bahan matriks yang digunakan dalam penelitian ini adalah matriks resin polyester dan hardener-MEKPO. Untuk melarutkan lapisan di permukaan serat digunakan $\mathrm{NaOH}$, dengan cara dilarutkan dalam air dengan konsetrasi $5 \%$. Mirror Glaze untuk memoles cetakan agar tidak lengket sehingga mempermudah pada proses pencetakan dan pelepasan komposit pada saat mengering.

Pengujian tarik dilakukan dengan menggunakan mesin Universal Testing merek Simadzu type $A G S-X$. Parameter yang digunakan dalam uji tarik adalah load cell $1000 \mathrm{~kg}$ dengan kecepatan tarik $10 \mathrm{~mm} /$ menit yang dilengkapi alat penyimpanan data hasil uji secara otomatis pada komputer.

\section{Diagram alir penelitian}

Gambar 6 adalah diagram alir penelitian. Penelitian dimulai dengan kajian literatur dan survei lapangan, dan mempersiapkan alat dan bahan. Tahap selanjutnya adalah penguraian serat dan perendaman serat dalam $\mathrm{NaOH}$. Tahap selanjutnya adalah penganyaman serat sebelum dilakukan pembuatan komposit. Sebelum diuji tarik dan bending, dibuat spesimen uji dengan bahan komposit. Hasil data dari pengujian ini akan dianalisa.

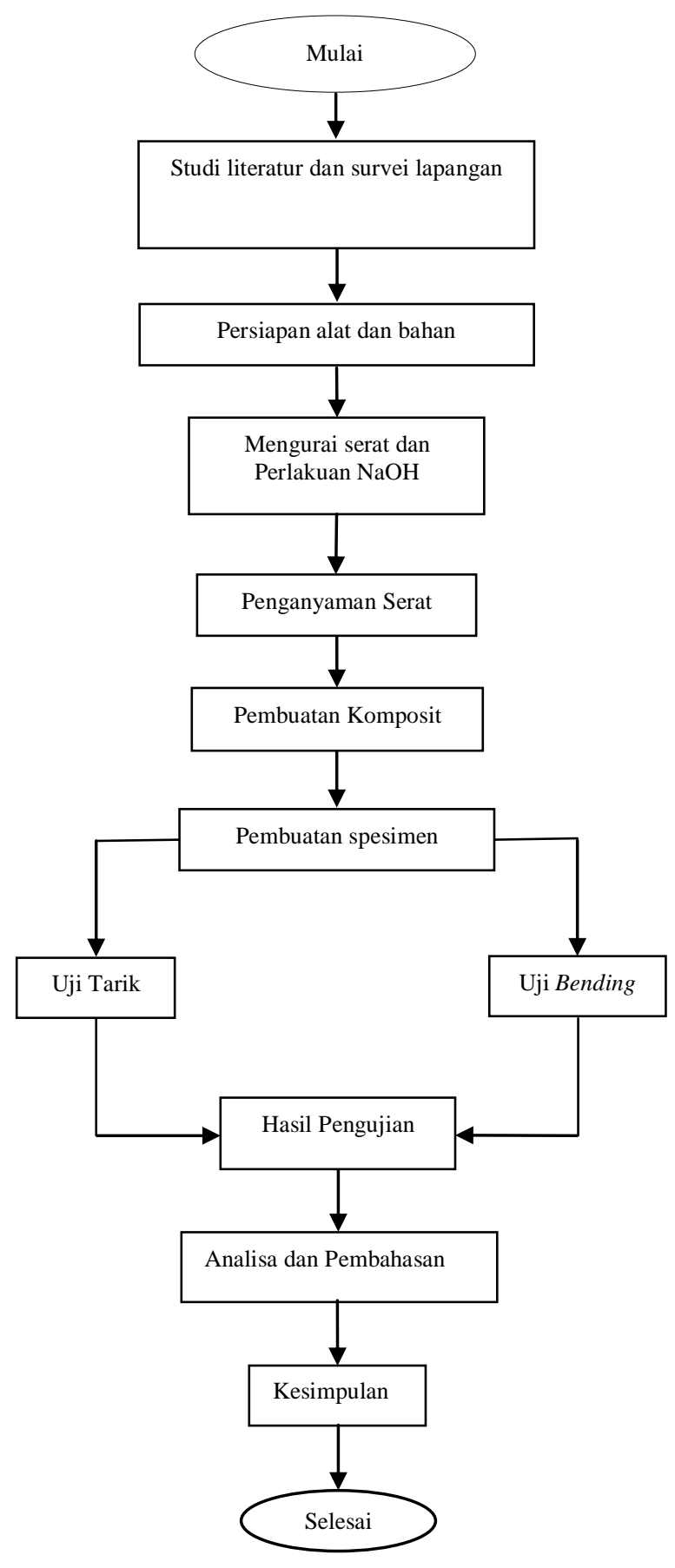

Gambar 6. Diagram alir penelitian 


\section{Hasil dan Pembahasan}

\section{Pengujian tarik}

Gambar 7, menunjukan hasil pengujian tarik pada spesimen uji. Pada spesimen plain, garis yang dibentuk lurus dan putus pada titik maksimum. Pada spesimen twill garis yang dibentuk tidak lurus, tetapi terdapat lekukanlekukan sebelum mencapai titik maksimum.

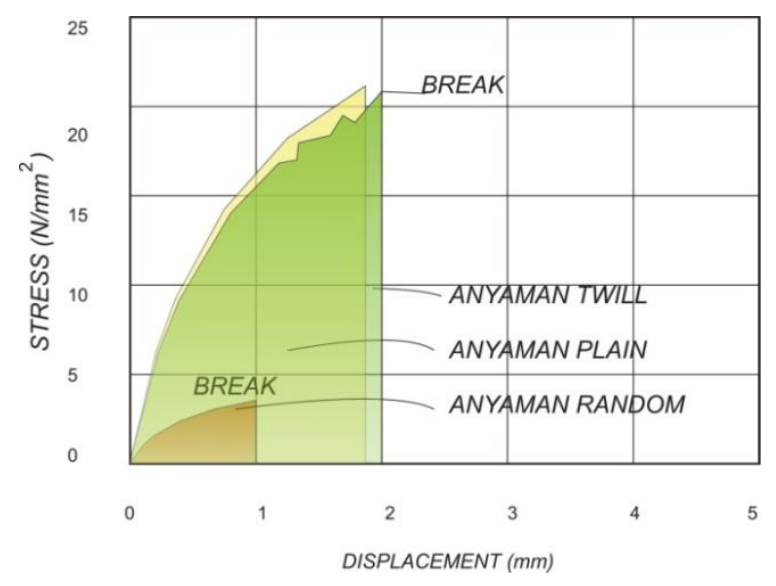

Gambar 7. Hasil uji tarik pada beberapa tipe anyaman

Fenomena yang terjadi pada spesimen twill disebabkan pada saat dilakukan pengujian, spesimen tersebut mengalami putus pada matriks terlebih dahulu, namun beban tersebut masih mampu diterima oleh serat. Hal ini menyebabkan garis yang dibentuk pada grafik menyerupai yielding sebelum mencapai titik maksimum.

Dari hasil pengujian pada pada spesimen plain dan twill, menunjukan bahwa dalam suatu komposit tidak memiliki sifat yang homogen pada setiap titiknya. Hal ini didukung oleh pendapat Matthews dkk (1994) yang menyatakan bahwa komposit merupakan suatu material yang terbentuk dari kombinasi dua atau lebih material pembentuknya melalui campuran yang tidak homogen, di mana sifat mekanik dari masingmasing material pembentuknya berbeda.

Dari gambar 8 dapat dilihat nilai kekuatan tarik dari masing-masing anyaman serat bambu. Nilai rata-rata kekuatan tarik tertinggi terdapat pada komposit dengan anyaman plain (20.234 $\mathrm{N} / \mathrm{mm}^{2}$ ), pada komposit dengan anyaman twill sebesar $20.163 \mathrm{~N} / \mathrm{mm}^{2}$ dan pada anyaman random sebesar $3.451 \mathrm{~N} / \mathrm{mm}^{2}$.
Kekuatan tarik tertinggi pada komposit serat bambu dengan anyaman plain disebabkan oleh ikatan antara serat yang lebih kuat karena adanya interface serat-matriks yang lebih banyak. Struktur anyaman plain dengan pola satu naik satu turun, membuat serat tidak mudah bergeser dari tempatnya dan jumlah silangan paling banyak antara serat yang satu dengan yang lain juga membuat anyaman plain menjadi lebih kokoh dan kuat. Hal ini membuat gaya yang diteruskan dari martiks mampu ditahan oleh serat.

Kekuatan tarik anyaman random $\left(3.451 \mathrm{~N} / \mathrm{mm}^{2}\right)$ sangat rendah bila dibandingkan dengan anyaman plain dan twill. Pada anyaman ini terjadi banyak kekosongan yang dapat menyebabkan penurunan nilai kekuatan tarik komposit. Hal ini disebabkan ketika komposit menerima beban, maka daerah tegangan akan berpindah ke daerah void, sehingga konsentrasi tegangan terjadi pada daerah tersebut. Karena pada daerah ini tidak terisi penuh oleh serat dan matriks, maka daerah ini menjadi titik terlemah yang dapat menjadi awal terjadinya kegagalan pada saat komposit menerima beban.

Jenis patahan dari ketiga anyaman komposit serat bambu dapat dilihat pada foto makro hasil pengujian tarik pada gambar 8 . Berdasarkan foto ini, dapat dilihat bahwa ketiga spesimen uji mengalami kegagalan yang sama, dimana serat tercabut dari matriksnya atau biasa disebut fiber pull out.

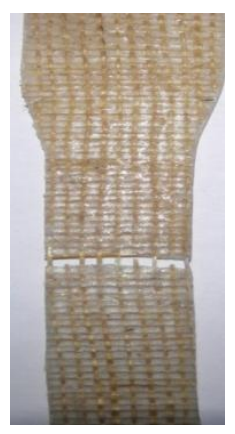

(a)

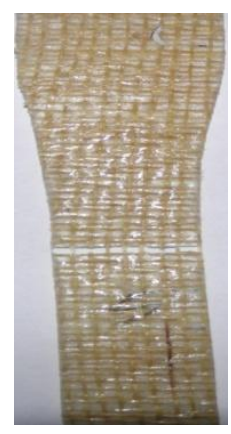

(b)

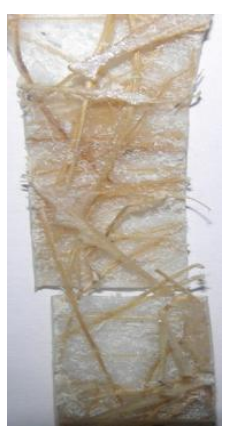

(c)
Gambar 8. Spesimen setelah dilakukan pengujian tarik (a) Spesimen komposit dengan anyaman plain, (b) Spesimen komposit dengan anyaman twill.

(c) Spesimen komposit dengan anyaman random 


\section{Pengujian bending}

Hasil dari pengujian bending pada komposit dapat dilihat pada gambar 9 berikut:

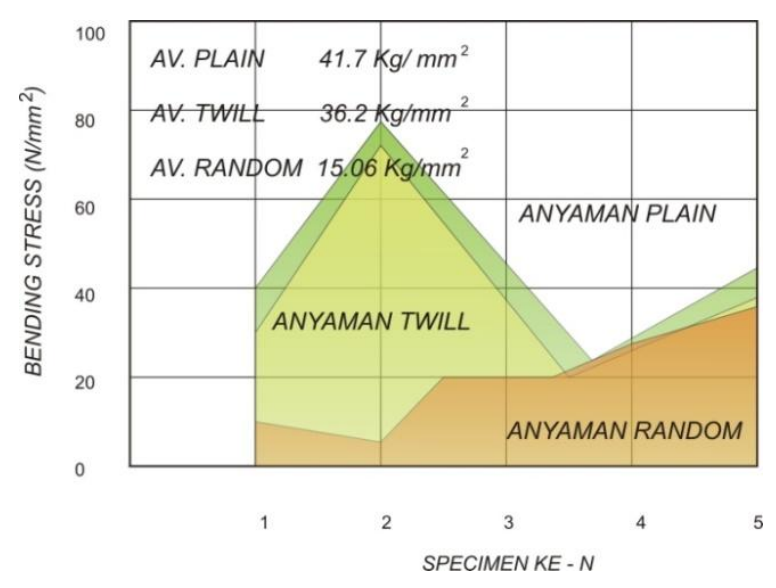

Gambar 9. Data hasil uji bending pada masingmasing jenis anyaman komposi serat bambu

Dari gambar 9, pada komposit serat bambu anyaman plain, nilai kekuatan bending adalah $41.707 \mathrm{~N} / \mathrm{mm}^{2}$. Pada komposit serat bambu anyaman twill kekuatan bendingnya adalah $36.206 \mathrm{~N} / \mathrm{mm}^{2}$ dan komposit serat bambu anyaman random nilainya adalah $15.061 \mathrm{~N} / \mathrm{mm}^{2}$.

Dari hasil ini, dapat dilihat perbedaan nilai yang sangat signifikan dari setiap pola anyaman. Hal ini disebabkan oleh pola anyaman yang berbeda. Pola anyaman satu naik satu turun membuat anyaman plain lebih kuat dari anyaman twill dan random. Kekuatan bending yang baik pada anyaman plain juga disebabkan oleh terjadinya interface antar serat-matrik yang baik sehingga komposit menjadi lebih kuat.

Kekuatan bending anyaman random yang sangat rendah dapat disebabkan oleh kurangnya ikatan (mechanical bonding) antar serat- matriks dan nilai interface yang sangat rendah. Hal ini dipengaruhi oleh susunan serat yang tidak teratur sehingga penyebaran matriks tidak mampu membasahi seluruh bagian serat. Jenis patahan dari ketiga anyaman komposit serat bambu dapat dilihat pada foto makro hasil pengujian bending pada gambar 10 .

Dari foto makro di atas dapat dilihat bahwa kegagalan yang terjadi pada serat random terjadi di daerah yang kosong. Hal ini menyebabkan anyaman random memiliki nilai yang rendah bila dibandingkan nilai anyaman plain dan twill.

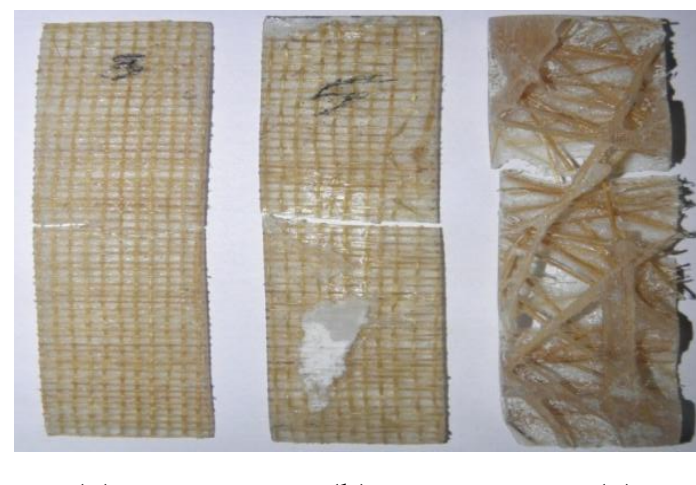

(a)

(b)

(c)

Gambar 10. Spesimen setelah dilakukan pengujian. (a) spesimen komposit dengan anyaman plain, (b) spesimen komposit dengan anyaman twill, (c) spesimen komposit dengan anyaman random

\section{Kesimpulan dan Saran}

Dari hasil pengujian, pola anyaman berpengaruh terhadap kekuatan tarik dan bending komposit serat bambu. Hasil pengujian tarik menunjukan nilai uji tarik tertinggi terdapat pada komposit dengan anyaman plain $\left(20.234 \mathrm{~N} / \mathrm{mm}^{2}\right)$, sedangkan nilai kekuatan tarik terendah terdapat pada anyaman random $\left(3.450 \mathrm{~N} / \mathrm{mm}^{2}\right)$. Hasil pengujian bending menunjukan nilai tertinggi terdapat pada komposit dengan anyaman plain $\left(41.707 \mathrm{~N} / \mathrm{mm}^{2}\right)$, sedangkan nilai kekuatan bending komposit terendah terdapat pada anyaman random $\left(15.061 \mathrm{~N} / \mathrm{mm}^{2}\right)$.

\section{Daftar Pustaka}

Alimaskur, 2011. Pengaruh Susunan Bambu Terhadap Kekuatan Komposit Beton. Skripsi, Fisika. Universitas Andalas, Padang.

Bismarck A, Askargorta IA, Lamphe T, Wielaye B, Stamboulis A, Skenderovich I, Limbach HH. 2002, "Surface Characterization of Flax, Hemp and Cellulose Fibres: Surface Properties and the Water Uptake Behavior", Polymer CompositeVol 23, no. 5.

Biswas. 2001, "Develpoment of Natural Fibre Composites in India, 2001 Convention and 
Trade Show", Composites Fabricators Association, Florida USA.

Diharjo K. 2006, "Pengaruh Perlakuan Alkali terhadap Sifat Tarik Bahan Komposit Serat Rami-Polyester". Vol. 8, No. 1. Jurusan Teknik Mesin Fakultas Teknik. Universitas Negeri Sebelas Maret. Surakarta.

Gibson. 1994, "Principle Of Composite Material Mechanics”. New York:Mc Graw Hill,Inc.

Hendra M. 2002,"Pengendalian Bahan Komposit”, Fakultas Teknik, Jurusan Teknik Kimia, Universitas Sumatera Utara.

Janssen. JJA. 1987, "The Mechanical Properties of Bamboo". 250-256.

Jones MR. 1975, "Mechanics of Composite Material", Mc Graww Hill Kogakusha, Ltd.

Matthews FL, Rawling RD. 1994, "Composite Material Engineering Science Technology and Medicine". London.

Morisco. 1999, "Rekayasa Bambu”, Nafiri Offset, Yogyakarta.

Pramono C. 2008, "Pengaruh Larutan Alkali dan Etanol Terhadap Kekuatan Tarik Serat Enceng Gondok dan Kompatibilitas Serat Enceng Gondok pada Matrik Unsaturated Polyester Yukalac tipe 157 BQTN-EX", Skripsi, Jurusan Teknik Mesin UNDIP, Semarang.

Rabiul SM. 2013, “Analisa Kekuatan Tarik Dan Densitas Komposit Polimer Berpenguat Serbuk Cangkang Telur'. Fakultas Teknik Universitas Haluoleo Kendari ( Skripsi ).

Rowell RM. 1997, "Chemical Modification “ Wood " in Haandbook of Wood Composit”. France.

Schwartz MM. 1984, "Composite Material Handbook". Mc. Graw Hill: Book Company.

Simbolon TR. 2008, "Ilmu Material". Departeman Fisika Universitas Suamatra Utara
Taufik MI, Sugiyanto., Zulhanif. 2013, "Perilaku Creeppada Komposit Polyester dengan Serat Kulit Bambu Apus (gigantochloa apus (j.a \& j. H. Schultes) kurz)", Volume 1, Nomor 1, Fakultas Teknik Universitas Lampung. Bandar Lampung.

Taurista. 2006, “ Komposit Laminat Bambu Serat Woven Sebagai Bahan Alternatif Pengganti Fiber Glass Pada Kulit Kapal”, Jurusan Teknik Material, Institut Teknologi Sepuluh Nopember, Surabaya.

Vlack V. 2005, "Ilmu dan Teknologi Bahan", Erlangga Jakarta.

Widjaja, E. A. 2001. Identikit Jenis-Jenis Bambu di Kepulauan Sunda Kecil, Pusat Penelitian dan Pengembangan Biologi LIPI, Bogor, Indonesia. 
DINAMIKA Jurnal Ilmiah Teknik Mesin 